\title{
PENGARUH PERANGKAT KERAS KOMPUTER DALAM SISTEM INFORMASI MANAJEMEN
}

The Effect Of Computer Hardware In Management Information Systems

Putri Majdina Simanullang

Prodi Sistem Informasi, Fakultas Sains Dan Teknologi, UINSU

putrimajdina@gmail.com

\begin{abstract}
The development of management information systems today has undergone many major changes in the organizational model and management decision making at all operational (technical implementation) and leadership levels. When writing management information systems, it will address topics related to the use of information technology, its effects, and the importance of the management decision-making process. Therefore, more understanding is needed to improve the quality of decision making and to explain its methods and effects. Using the development of management information systems in the decision-making management information system itself.
\end{abstract}

Keywords:

Computer hardware; Information Systems; Information

\begin{abstract}
Abstrak
Perkembangan sistem informasi manajemen pada saat ini telah mengubah banyak perubahan besar dalam model pengambilan keputusan organisasi dan manajemen di semua tingkat operasi (implementasi teknis) dan kepemimpinan. Saat menulis sistem informasi manajemen, ini akan membahas topik yang berkaitan dengan penggunaan teknologi informasi, efeknya, dan pentingnya dalam proses pengambilan keputusan manajemen. Oleh karena itu, diperlukan lebih banyak pemahaman untuk meningkatkan kualitas pengambilan keputusan dan untuk menjelaskan metode dan pengaruhnya. Menggunakan pengembangan sistem informasi manajemen dalam pengambilan keputusan manajemen sistem infomasi itu sendiri.
\end{abstract}

Kata kunci:

Perangkat Keras komputer; Sistem Informasi; Informasi

\section{PENDAHULUAN}

Sistem informasi adalah unit komponen yang saling berhubungan yang mengumpulkan (atau mengambil), memproses, menyimpan, dan mendistribusikan informasi untuk mendukung pengambilan keputusan dan pengendalian dalam organisasi.Selain itu, sistem informasi juga dapat membantu manajer memeriksa masalah dan memvisualisasikan solusi. Kompleksitas dan poin kunci dalam menciptakan produk baru dapat dikatakan bahwa sistem informasi ialah serangkaian prosedur dasar formal yang digunakan untuk mengumpulkan data. Sistem informasi adalah kombinasi dari 
berbagai sumber daya, termasuk perangkat keras, perangkat lunak, perangkat lunak jaringan, perangkat lunak otak, dan data. Dalam sebuah sistem informasi juga terdapat input, model, proses, output, penyimpanan dan pengendalian, sehingga sistem informasi dapat digunakan untuk merencanakan, mengolah, dan mengontrol data dalam organisasi untuk menentukan apakah sistem tersebut berhasil.

Pada artikel ini saya akan emmbahas lebih dalam lagi, tentang apa peranan dan pengaruhnya perangkat keras komputer dalam sistem infomasi manajemen saat ini. Selain itu saya akan menunjuikkan atau membuktikan pengaruh besarnya melalui tahapan perkembangan sistem informasi manajemen yang saat ini sangat pesat hingga memeperngaruhi sebagian besar dari kehidupan manusia.

\section{STUDI LITERATUR}

Studi Liberatur yang dimana saya telah melakukan pengambilan beberapa informasi dari berbagai macam buku, artikel, makalah, skripsi jurnal dan website informasi lainnya. Pasa artikel ini juga saya hanya fokus membahas tentang peranan dan Pengaruh perangkat keras Komputer dalam Sistem Informasi Manajemen sesuai dengan judul yang telah saya buat.

\section{METODE PENELITIAN}

Artikel ini saya buat dalam sifat penelitian pustaka yang dimana data yang saya peroleh adalah sebuah kajian dengan pokok rumusan masalah dan disesuaikan dengan judul pokok atau rumusan masalah yang ada pada artikel ini. Tujuan dari artkel ini adalah untuk menginput data dan mengumpulkan data atau informasi yang dikekola kembali. Artikel ini bersumber dari berbagai macan sumber berupa kumpulan buku, junal, karya ilmiah, makalah dan artikel lainnya.

\section{HASIL DAN PEMBAHASAN}

\section{A. Pengertian Sistem Komputer}

Sistem merupakan suatu kesatuan pada komponen yang dihubungkan bersama untuk memudahkan aliran informasi, materi atau energi. Sistem juga merupakan kesatuan dari bagianbagian yang diaman kesatuan itu saling terhubungan dan memiliki item-item penggerak.

Beberapa ahli menyebutkan beberapa definisi komputer, antara lain:

1. Hamach beropini bahwa personal komputer merupakan personal komputer elektro cepat yg bisa mendapat warta input digital, lalu memprosesnya sinkron menggunakan acara yg tersimpan pada memorinya, dan membentuk hasil berupa warta.

2. Menurut Blissmer, personal komputer merupakan perangkat elektro yg sanggup melakukan tugas-tugas berikut: satu jenis, Terima masukan, Input diproses sinkron acara, Simpan perintah dan output pemrosesan dan menaruh keluaran berupa warta.

\section{B. Definisi jenis perangkat keras dam komponen}

Perangkat keras personal komputer merupakan seluruh bagian fisik personal komputer , perbedaannya terletak dalam data yg berada pada dalamnya atau berjalan pada atasnya dan tidak selaras menggunakan software yg menaruh instruksi pada perangkat keras buat menuntaskan tugasnya.Semua perangkat 
input umum adalah mereka yang memecahkan kode (mengubah) informasi tertentu menjadi data yang dapat diproses lebih lanjut oleh sistem komputer digital.

Perangkat output yang menerjemahkan data menjadi informasi yang dapat dipahami oleh pengguna komputer.

1. Perangkat masukan

Ini adalah sejenis perangkat keras komputer, yang digunakan sebagai alat untuk memasukkan data ke dalam komputer melalui keyboard, pemindai, mouse, dll.

\section{Output Device}

Merupakan perangkat keras komputer yang berfungsi untuk menampilkan keluaran dari hasil data yang telah kita buat.

\section{3) Storage Device}

Merupakan Register berukuran kecil, dan CPU biasanya harus dilengkapi dengan alat penyimpan dengan kapasitas besar karena CPU yang berukuran kecil. Memori utama biasanya terbagi menjadi dua yaitu :

1. Internal Storage merupakan media penyimpanan didalam komputer yaitu :

a. RAM Untuk menyimpan program yang kita olah untuk sementara waktu. Dapat diisi/ditulis, diambil, atau dihapus isinya.

b. ROM Merupakan Memori yang hanya bisa dibaca dan berguna sebagai penyedia informasi pada saat komputer pertama kali dinyalakan.

\section{External Storage}

Merupakan Perangkat keras yang dimana bertugas melakukan operasi penulisan, pembacaan dan penyimpanan data, di luar komponen utama sepeeti Floppy Disk, Hard Disk, Room dan DVD

C. Mengetahui sistem informasi
pakar

Selain pengertian umum tentang sistem informasi, beberapa ahli telah mengusulkan definisi sistem berita, seperti yang ditunjukkan di bawah ini:

- Menurut John F Nash (John F Nash), sistem informasi mengacu pada kombinasi beberapa personel dan akal sehat teknis, media online, mekanisme terstruktur, dan kontrol yang bertanggung jawab untuk mengelola jaringan komunikasi untuk melakukan beberapa manajemen urusan harian internal dan eksternal proses, menjadi dasar pengambilan keputusan.

- Menurut Erwan Arbie, sistem informasi adalah suatu sistem yang dibentuk dalam suatu organisasi yang bertugas untuk memenuhi kebutuhan berbagai transaksi yang terjadi seharihari untuk bantuan, juga sebagai penunjang selama operasional. Menurut forum, ini pada dasarnya bersifat administratif dan menyediakan laporan permintaan yang disinkronkan.

-Menurut O’Brien, sistem informasi adalah sistem gabungan yang mengatur seseorang menurut unitnya masingmasing, penggunaan perangkat keras, perangkat lunak, jaringan komputer, jaringan komunikasi dan pengolah database yang dikumpulkan satu sama lain, mengubah proses dan menampilkan informasi tentang bentuk organisasi berita.

- Menurut Mc Leod, kesimpulan yang dapat diambil dari Mc Leod adalah sistem informasi adalah sistem yang dapat mengumpulkan dan menampilkan 
berita dari banyak sumber dan digunakan oleh banyak media.

- Menurut Agus Mulyanto, sistem informasi mengacu pada komponen yang terdiri dari mekanisme kerja yang bertanggung jawab untuk memproses, menganalisis, menyimpan dan menampilkan berita, pengaturan teknis untuk mencapai tujuan, dan persepsi pengguna.

- Menurut Tafri D. Muhyuzir,

D. Muhyuriz mengemukakan bahwa sistem informasi adalah kombinasi dari data yang diproses, dan dilakukan pengklasifikasian sebagai akibatnya tercipta sebuah kabar entitas yg saling terkait juga tunggal dan tercipta sebuah sistem infomasi.

\section{Sistem Informasi Manajemen}

Sistem informasi manajemen ialah bagian penting dalam pengendalian bagian inti. Sistem informasi manajemen biasanya kita dengar dan kita pelajari disekolah dan perkuliahan sebagai sebuah sistem manusia/mesin yang dan diguankan untuk memberikan kita informasi untuk mendukung fungsi operasi, manajemen, dan pengambilan keputusan dalam sebuah organisasi, baik itu organisasi kecil maupun besar.

Sistem Informasi Manajemen merupakan hal penting dalam sebuah akutansi infomasi yang terpengaruh dalam sebuah sistem yang bekerja agar bejalan secara harmonis untuk menghasilkan informasi yang dapat dipercaya oleh para pemakai informasi. Pada dasarnya konsep sistem infomasi manajemen mengintergrasikan semua unsur yang terkait dalam suatu sistem informasi manajemen untuk mencapai kualitas yang baik,
Berikut beberapa dasar penting sistem informasi manajemen sebagai berikut:

- perangkat keras, peralatan phisik yang dapat digunakan untuk mengumpulkan, memasukkan, memproses, menyimpan, dan mengeluarkan hasil pengolahan data dalam bentuk informasi,

- perangkat lunak, sekumpulan programprogram dari komputer yang digunakan untuk menjalankan komputer atau aplikasi tertentu pada computer,

- Brainware, berupa sumber daya manusia atau kita sendirisebagai bagian terpenting dari komponen untuk sistem informasi manajemen,

- Prosedur, melakukan rangkaian aktivitas atau kegiatan yang dilakukan secara berulang-ulang dengan cara yang sama,

- Basis data, bisa didefinisikan sebagai sekumpulan data yang saling terkait sehingga memudahkan proses pencarian informasi

- komunikasi data dan jaringan komputer

\section{E. Sistem Informasi Manajemen}

Melalui contoh, bentuk sistem informasi manajemen akan lebih mudah dipahami. Untuk kejelasan, Berikut lebih lanjut:

1. Sistem Pendukung Eksekusi Sistem di atas akan membantu manajer untuk berinteraksi dengan lingkungan perusahaan. Yaitu, melalui penggunaan bantuan grafis dan dukungan komunikasi lainnya. 
2. Sistem Pendukung Keputusan Grup (GDSS) dan Sistem Kerja Kerja Sama yang Didukung Komputer (CSCWS) Fungsi GDSS adalah menemukan solusi untuk masalah guna mengumpulkan pengetahuan di antara kelompok daripada individu. GDSS biasanya berbentuk kuesioner, konsultasi dan skenario. Contoh GDSS adalah e-government.

3. Sistem Pakar (SP) dan Kecerdasan Buatan (AI) Sistem informasi menggunakan kecerdasan buatan untuk menganalisis solusi masalah dan menggunakan pengetahuan ahli yang telah dimasukkan ke dalamnya. Contoh AI adalah sistem pengiriman mekanis.

4. Sistem Pendukung Keputusan (SPK) Selain itu, terdapat sistem informasi yang dapat membantu manajer dalam mengambil keputusan dengan memperhatikan lingkungan internal perusahaan. Contoh dari DSS adalah electronic link.

\section{Sistem Manajemen Informasi}

(IMS) IMS memiliki fungsi untuk mendukung serangkaian tugas dalam suatu organisasi. IMS juga dapat digunakan untuk analisis dan pengambilan keputusan. Berbagai fungsi informasi dan program komputer dapat diintegrasikan ke dalam satu IMS.

\section{Sistem Otomasi Kantor} Contoh sistem informasi selanjutnya adalah OAS atau sistem otomatisasi kantor. Aplikasi ini memiliki fungsi untuk memfasilitasi komunikasi antar departemen internal perusahaan. Caranya adalah dengan mengintegrasikan komputer server di setiap perusahaan pengguna. Contoh OAS adalah melalui email.
7. Manajemen Rantai Pasokan Dalam sistem manajemen ranai, manfaat dari manajemen adalah integrasi data penting, seperti pasokan dari pemasok, produsen hingga pengecer. Bahkan, untuk konsumen akhir. Biasanya sistem ini terintegrasi dengan sistem pembukuan perusahaan pada software akuntansi.

8. Perencanaan Sumber Daya Perusahaan (ERP) Banyak perusahaan besar menggunakan sistem informasi manajemen ERP. Namun, sistem tersebut juga dapat digunakan dalam skala kecil. ERP biasanya digunakan untuk manajemen dan pengawasan komprehensif antar unit perusahaan.

\section{F. Dasar- dasar Komputer}

Seperti yang kita ketahui dimana pada Sistem yang ada pada komputer biasanya memiliki komponen dibedakan atau terbagi menjadi tiga yaitu hardware, software, dan brainware. Pada komponen ini memiliki peranannya masing-masing dan memiliki kelebihan maupun kekurangnanya masing-masing seperti:

1. Hardware atau Perangkat Keras yang merupakan peralatan fisik yang dapat kita sentuh dan bisa kita lihat langsung.

2. Software atau Perangkat Lunak merupakan perangkat komputer yang tidak dapat disentuh secara fisik karena berbentuk program yang terdiri dari instruksi/perintah untuk melakukan pengolahan data.

3. Brainware atau Perangkat Pemakai merupakan kita yang berperan sebagi pemakai yang akan mengoperasikan dan mengendalikan sistem komputer sesuai dengan apa yang kita mau. 
Pada sistem informasi ini tiga komponen ini akan saling berkeja sama untuk membuat atau menginput data yaitu:

- proses input data yang dimana merupakan kegiatan perpindahan atau emmindahkan data untuk masuk ke sistem yang ada pada komputer agar data bisa digunakan dan disimpan melalui pengimpanan yang akan kita muat dalam bentuk file

- Pemprosesan data merupakan proses pengolahan yang akan dimuat dalam bentuk informasi

- Proses menghasilkan output berupa produk informasi dan sekumpulan data yang dikelola menjadi nilai yang menghasilkan infomasi.

\section{G. Proses perangkat keras fungsional dalam sistem manajemen informasi}

Sistem operasi berperan untuk mengendalikan sistem komputer yang satu dengan lainnya. Memberikan izin aplikasi maupun akses web lainnya untuk mengoperasikkannya bersama dengan peralatan komputer lainnya. Sistem Operasi juga memiliki beberapa sistem salah satunya yaitu menerjemahkan bahasa dengan tingkat tinggi dengan menngunakan pengkompilasi (compiler) dan penerjemah (interpreter) yang akan mengelola melalui program untuk dijalankan bersama.

Berhubunga dengan fungsifungsi itu, biasanya auditor akan emlalukan tugasnya untuk memastikan bahwa tujuan pengendalian atas sistem operasi yang sedang kita jalankan berjalan baik dan sesuai dengan prosedur-prosedur pengendalain.

Ada beberapa tujuan dari pengendalian sistem operasi sebagai berikut: a. Mencegah agar akses tekendali dan tidak merugikan sistem operasi maupun arsip data

b. Mengendalikan pengguna yang satu dari pengguna lainnya agar seorang pengguna tidak dapat menghancurkan atau mengkorupsi program atau data pengguna lainnya.

c. Mencegah program seseorang dirusak oleh orang lain

d. Mencageh bencana pada Sistem Operasi seperti kerusakan internal maupun eksternal lainnya.

Risiko-risiko yang mungkin dihadapi oleh sistem operasi dalam penggunaannya sebagai berikut:

a. Penyalahgunaan akses sistem operasi oleh pengguna seperti layaknya manajer sistem.

b. penyalahgunaan oleh para pengguna dan hanya dia yang beruntung.

c. kerusakan sering yang terjadi pada sistem yang silakukan oleh para pengguna

- Pengendalian Sumberdaya Data Prosedur pengendalian sistem operasi yang biasanya dijalankan adalah sebagai berikut:

a. Satu jenis. Berikan atau kendalikan kata sandi.

b. Pastikan kontak dengan karyawan.

c . Nyatakan kepada pengguna bahwa mereka bertanggung jawab atas penggunaan sistem yang benar dan untuk memastikan kerahasiaannya.

d. Membentuk kelompok keamanan untuk memantau dan melaporkan pelanggaran.

e. Tetapkan kebijakan formal untuk penjahat.

- Pengendalian sumber daya data 
Resiko-resiko yang mungkin dan biasanya berkaitan dengan Sumberdaya Data yaitu degan adanya bencana kebakaran, banjir, dan sebagainya. Begitu juga kerugian seperti kelalaian dapat tanpa sengaja menghilangkan data, mencuri atau bahkan menghancurkan data.

Untuk memakai asal daya data secara efektif, efisien dan hemat, mekanisme yg wajib diadopsi buat mengontrol asal data meliputi:

a. Buat file data cadangan.

b. Data disimpan pada lokasi terpisah buat pencadangan dan pengarsipan.

c. Otorisasi berbasis istilah sandi dan penggunaan memilih akses terbatas ke file data.

d. Menggunakan teknologi biometrik (misalnya voice, finger atau retinal imprinting) buat akses data yg beresiko tinggi.

e Batasi fungsi query sebagai akibatnya data sensitif nir bisa dibaca.

F. Cadangkan semua database secara teratur.

g. Buat acara pemulihan buat memulai sistem berdasarkan file cadangan dan register transaksi.

Pengendalian pengembangan sistem Risiko pada pengembangan sistem meliputi: membuahkan sistem tidak penting, tidak berguna, tidak hemat atau tidak bisa diaudit. Program pengendalian yg dikembangkan sang sistem merupakan menjadi berikut:

a Otorisasi penuh berdasarkan sistem buat menaruh bukti rasionalitas \& kelayakan ekonomi;

b. pelibatan pengguna pada pengembangan sistem;

c. Partisipasi pengguna pada pengembangan sistem;

d. Catat sepenuhnya seluruh aktivitas pengembangan; d. Melibatkan auditor pada aktivitas pengembangan sistem;

e. Pengujian menyeluruh terhadap holistik acara, terutama akurasinya (menggunakan membandingkan output pengujian acara menggunakan output yg diharapkan) \& reliabilitas.

- Sistem Komputer

Sistem Komputer adalah penyalur yang saling berkaitan dan befungsi untuk menjalankan aktifitas menggunakan komputer. Ada 4 pembagian elemen dari sistem komputer yaitu perangkat keras atau hardware, Sofware atau perangkat lunak, set instruksi atau instruction set, dan manusianya atau brainware.

Perangkat keras adalah perangkat yang dapat dilihat dengan mata telanjang dan dapat disentuh. Dalam perangkat keras: peralatan pemrosesan, peralatan input, peralatan output, peralatan penyimpanan.

1) CPU (Central Processing Unit) yang berperan untuk memproses arahan dan melaksanakan pengurusan melalui inforamasi pasa sistem komputer. Dengan peranti atau unit yang ada pasa sistem komputer juga akan melakukan arahan-arahan yang berkaitan dengan arahan melalui informasi yang telah dimuat.

2) Input and Output Device yang dapat berrfungsi untuk medaparkan informasi dari luar baik itu dalam bentuk fisik maupun nonfisik. Beberapa macam alat Input and Output Device mulai dari yang sering kita temui seperti keyboard, monitor, disk drive, kamera, web, printer, scanner, dan masih banyak lagi.

3) Perangkat penyimpanan mendaftarkan CPU kecil sehingga tidak 
dapat menyimpan semua informasi, oleh karena itu CPU harus dilengkapi dengan perangkat penyimpanan dengan kapasitas yang lebih besar yaitu memori utama.

\section{KESIMPULAN}

Sepeti yang kita ketahui, peningkatan penggunaan Sistem Informasi dan Teknologi informasi khususnya internet, telah memperoleh banyak perubahan yang dimana kita dapat melakukan berbagai macam aktivitas dengan tingkat keakuratan yang berkualitas dan yang lebih baik lagi. Setiap organisasi dapat memanfaatkan internet dan jaringan teknologi informasi untuk menjalankan berbagai aktivitasnya secara elektronis. Seiring dengan perkembangan jaman dan semuahal yang semakin maju padasaat ini sangat berhubungan dengan Manajemen. Mulai dari mentalitas, keuangan, organisasi, dan lain sebagainya salah satu komponen sistem informasi manajemen. Pencapaian sistem informasi manajemen menghasilkan informasi yang akurat, rinci, tepat waktu dan relevan sangat bergantung pada daasar-dasar ini.

Dengan cara ini, tujuan perusahaan atau organisasi dalam penerapan sistem informasi manajemen dapat tercapai seluas-luasnya, dan memiliki nilai guna yang tinggi. Oleh karena itu peran dan pengaruh perangkat keras dalam sistem informasi manajemen merupakan salah satu komponen penting dari sistem informasi. Ketika menghasilkan informasi yang berguna untuk manajemen dalam proses yang akan direalisasikan, manajemen sangat penting, dan harus dipertimbangkan dan sama pentingnya dengan komponen lainnya Perangkat keras komputer memiliki pengaruh yang besar terhadap sistem informasi manajemen (SIM).

Sistem Informasi Manajemen terdiri dari beberapa fungsi sebagai berikut:

- Mendorong peningkatkan produktivitas dan penghematan dalam pembayaran di dalam organisasi;

- Mendorong peningkatkan kualitas dari sumber daya manusia dikarenakan unit sistem kerja akan lebih terkoordinasi serta sistematis;

- Mempermudah pihak manajemen dalam melakukan pengawasan, perencanaan, pengarahan serta pendelegasian kinerja pada semua departemen yang mempunyai koordinasi dan hubungan;

- Mendorong peningkatkan efisiensi serta efektivitas data yang lebih tepat waktu dan akurat.

Manfaat Sistem Informasi Manajemen memiliki beberapa manfaat yang penting dalam keberlangsungan organisasi atau perusahaan. Ada beberapa manfaat yang akan didapat sebagai berikut:

1. Anda dapat mencari informasi penghitungan harga sebuah produk , harga dasar produk, jasa, serta tujuan lain yang diinginkan oleh manajemen.

2. Anda bisa mencari informasi yang bisa digunakan untuk merencanakan, mengendalikan, mengevaluasi, serta melakukan perbaikan yang berkelanjutan.

3. Terdapat juga infomasi dimana anda dapat menggunakannya dalam mengambil keputusan penting.

Seperti penjelasan yang telah saya jawabrkan dalam artikel inni dapat kita putuskan bahwa pada saat sistem saling 
mendukung untuk mengelola managemen maka hasilnya akan sesuai dengan apa yang kita inginkan. Perencanaan dan pengembangan salam bentuk apapun itu akan menjaid lebih baik dan terukur lagi karena semua pendukng terhubung satu sama lain dan informasi yang dihasilkan menjadi lebih baik.

\section{DAFTAR PUSTAKA}

M, Fakhri Huseindan A, Wibowo.2002. Sistem Informasi Manajemen, edisis Revisi, UPP AMP YKPN Yogyakarta

Nonino, F,. (2012). Open innovation web, based platfoms of motivation on collaboration: Management: Management, policy ang pragtice Practice. 14(4),5557-575.

Hariandja. 2002. Manajemen Sumber DayaManusia, Pengadaan pengembangan Pengkoordinasian dan Peningkatan Produktivitas Pegawai, PT.Grasindo, Jakarta

Hariyanto, S. (1). "Sistem InformasiManajemen".JurnalPU BLICIANA,9(1),80-85.

Retrieved from ,Vol.9 No. 1 (2016).Bernard. 2005. An int

Brabham, D, C., (2008). Crowdsourcing sebagai model pemecahan masalah: pengenalan dan studi kasus. Konvergen: Jurnal Internasional Penelitian Teknologi Media Baru. 14 (1), 75-90.
Becker, P., (2002). Kehutanan Perusahaan di Eropa: Tinjauan pertama. Institut Sains dan Teknologi. Formulir pencarian ftp://ftp.cordis.europa.eu/pub/for esight/docs/st_corporate_foresig ht_040109.pdf

Jogiyanto. 2005. Sistem teknologiInformasi, Andi, Yogayakarta.

Widjadjanto, N,. (2001). Sistem Informasi Akuntansi. Jakarta: Penerbit Erlangga.

Romney, M., Steinbart, P, J., (2005). Accounting Information Systems 9thEdition. Jakarta: Penerbit Salemba Empat

Susanto, A,.(2004). Sistem Informasi Manajemen Konsep dan Pengembangannya. Bandung: Penerbit Lingga Jaya.

https://accurate.id/marketingmanajemen/sistem-informasimanajemen-arti-fungsi-contohdan-manfaatnya/

https://dosenpintar.com/pengerti an-sistem-informasi/

https://media.neliti.com/media/p ublications/284686pengambilan-keputusanberbasis-komputer-072aeb36.pdf

Bintoro, Jusuf \& Muhammad Yusro. Pengantar Teknologi Informasi. Lab. Teknologi informasi, jurusan teknik elektro, FT UNJ. 
http://www.perpus-

online.co.cc/makalah-sistem-

komputer.html 